\title{
THE APPLICATION OF BEHAVIORAL ECONOMICS TO REFORMING PENSION SYSTEMS - EVIDENCE FROM GREAT BRITAIN AND NEW ZEALAND
}

This article aims to evaluate the application of some of the solutions developed on the basis of the theory of behavioural economics in the practice of reforming pension systems. The research results presented regarding the use of behavioural economics in the reform of occupational pension schemes in Great Britain (automatic enrollment with a possibility of opting out at a certain time). The success of the British reform has been determined by the default option where an employee automatically enrolled in the occupational pension scheme is to remain in the program and co-pay contributions together with their employer. Quitting the program required taking the initiative and violating the status quo. In addition, a broad educational campaign has been launched, demonstrating a long-term benefit for both employees and employers (appropriate mental "formatting"), and the choice of an opt-out option (withdrawal in the first month and the recovery of the first contribution) as riskier (the mechanism of psychological risk aversion). The analysis of the implementation of occupational pension schemes with automatic enrollment demonstrates that the introduction of a similar solution in Poland constitutes a real chance for the dissemination of occupational pension schemes and would provide impetus to the development of the third pillar of the pension system in the country. The results achieved in these countries (dissemination of occupational pension schemes and an increase in the level of additional pension savings) are encouraging. On this basis, recommendations have been made on the possibility of applying similar solutions in Poland. The author also points to some of the dangers associated with the use of behavioural economics in the reform of pension systems (inter alia, manipulation of behaviour and decisions of participants not always in line with their interests, misspelling).

Keywords: behavioural economics, pension reforms, public and supplementary pension schemes.

Introduction. Studies of pension systems are interdisciplinary. They are conducted not only in the field of social sciences but also management, economics, finance, and demography. The dominant paradigm of the conducted research is based on the neoclassical economics theories, and in particular on the assumption about rationality of the economic entity (homo economics), acting in consequence, in accordance with the adopted preferences and aiming at maximizing one's own utility by choosing economic goods within the limits of budget limits. This approach prevails in the science of social policy and in pension economics. In general, explicitly or implicitly speaking, it is assumed that social policy actors (state, local governments, employers, households) act in a purposeful and rational way, although their decisions are not always optimal.

The task of social policy as applied science aims to provide theoretical knowledge and formulate directives addressed to practitioners serving the rationalization of social policy. According to Szumlicz (2005: 27-28), "one can assume that social policy as practical science examines changes taking place in the social structure under the influence of deliberate activities of groups and social institutions. On this basis, it formulates the postulates of rationalizing social policy as a practical activity". Meanwhile, social policy actors do not always act in a fully rational manner. This applies to both decision-makers who make strategic decisions on the level of redistribution of the developed social product, as well as employers and self-employed people who choose the height of social security contributions (frequently selecting legally permissible minimum rates despite being aware that it may negatively affect the level of future benefits 
from the public pension system).

It turns out that in reality, people make decisions in a way that differs from the homo oeconomicus model. This also applies to important pension issues: whether and how much additionally safe for old age, what financial instruments use for this purpose (bank deposits, mutual investment funds or other investment or savings instruments), whether retire immediately after reaching the statutory retirement age or better extend the professional activity.

A more realistic explanation of the actual behaviours of economic entities is provided by behavioural economics, still relatively recent - a niche, and since twenty years and especially in XXI century a dynamically developing trend in economic theory, an alternative to so-called mainstream economics.

Literature Review and the Problem Statement. The issue of rationality and irrationality in decisionmaking regarding the political sphere to date has been broadly penetrated in Polish literature on political science, e.g. in Szczupaczyński (1993) and Skrażyńska (2006), with extensive research on electoral decisions. There are relatively few research papers in the field of economic psychology in Polish (Skażyńska 1999, Tyszka, 1999, Zaleśkiewicz, 2011) but lots of publications in the world scientific literature (Camerer at al., 2004, Zinn, 2004). Behavioural economics is already being implemented in research on pension systems (Cordes,1990, Thaler, Bernarzi, 2000, Thaler, Sustein, 2008, Knoll, 2010) and its usefulness has been verified by pension reforms introduced in several countries, such as USA, New Zeeland and Great Britain.

The aim of the article is to evaluate the application of some of the solutions developed on the basis of the theory of behavioural economics in the practice of reforming pension systems. This serves to indicate the selected assumptions and research results based on behavioural economics regarding pension security systems and in particular the research at the micro level (decisions taken by participants affecting their level of financial security during old age after the end of their professional activity).

The presentation of selected ideas of behavioural economics and behavioural theories of saving serve as a starting point for further reflections. Subsequently, the paper examines the effects of behavioural economics on the introduction of occupational pension schemes reform in the UK (automatic enrollment of new workers meeting certain wage requirements into pension schemes) - as a case study of an implementation of behavioural economics in pension reforms.

Selected Objectives and Problem Areas of Behavioral Economics. Behavioural economics has appeared in response to unrealistic assumptions and a specific anti-psychology of the so-called mainstream economics. It is worth recalling the assumptions of the neo-classical school in economics that have been criticized. In a neoclassical economic model (sometimes called the standard model) - inspired by the works of such authors of the nineteenth or the beginning of the twentieth century as Jevons, Walras, Marshall and Pareto - explaining the behaviour and decisions of entities is based on the following basic assumptions:

- Individuals are rational.

- They operate by directing complete and excellent information, with unlimited processing possibilities.

- The purpose of their decisions is to maximize the expected usability (consumers) or profit (manufacturers).

- They operate in a narrowly understood self-interest, not taking into account the usefulness of other entities.

- They have coherent preferences also in a temporal system, that is embodied in a model of exponentially discounted utility.

- They make decisions based on logical reasoning.

- They treat their income and resources interchangeably, i.e. as unspecified regarding their origin and destination. 
Neoclassical decision-making theory is based on the concept of expected utility created in the 18th century by Bernoulli, and developed in the works of von Neuman and Morgenstern in the mid-twentieth century. This is a normative and non-descriptive theory. It indicates what action to take in a situation of choice in order to maximize the utility function. Moreover, the analyses of Marshall, A. and other mainstream economists have led to the development of a general model of the market economy. It is based on microeconomic decisions of producers and consumers, and price elasticity (including wages representing the price of human labour and interest rates representing capital). According to the law of supply and demand, the market is able to ensure balance also in macroeconomic terms.

It is apparent that the assumption of full rationality of entities utilizing full information and always acting in a consistent and self-interested way does not always correspond with reality. No wonder it has been met with criticism in the field of economics, but also in other social sciences. The problem, however, is to find an alternative cognitive perspective, broaden cognitive horizons with research that also considers the psychological aspects of retirement decision making in more realistic conditions with a limited access to information, uncertainty and risk, often under the influence of emotions, including volitional factors (hence the differences in the personalities of decision-makers in legal, institutional and economic-financial systems in a given country). Economic sciences have not yet been able to create a new paradigm that would replace the neoclassical school in microeconomics. Similarly, for pension economics it is still difficult to point to a new paradigm, a new strong theory or a group of logically related theories that would allow, in a coherent and holistic way (considering economic, institutional, sociological and psychological aspects), to explain real decisions and actions taken by pension system participants.

Work by Kahneman and Tversky (1979) on making decisions under risk was fundamental to behavioural economics. It was followed by Thaler's (1980) theory of choice. Those authors sought to extend the power of economic theory to provide them with the framework for experimental psychological research. Experiments conducted by Kahneman and Tversky concerning people's decisions under the conditions of uncertainty have indicated numerous anomalies in the actual decision-making processes that undermine the rational model of individual preferences (Kahneman, Tversky, 1979). The authors of the prospect theory have noted that people tend to overestimate certain events in favour of the highly probable ones (they call this a certainty effect). Another important observation regards the dependence of the choices made on the form of presentation of the decision-making process (framing effect). Prospect theory predicts that the preferences of decision-makers will depend on how the decision-making problems are formulated.

The main assumption of the prospect theory is that making financial decisions (economic ones) under risky conditions is determined by the perception of value offered by a given option (the chosen alternative). Moreover, not the absolute level of wealth is decisive here, but the changes to it (gains or losses). Entities evaluate available alternatives considering specific reference points, such as property, experience. "The value function is concave for gains (the further from the reference point the estimated opportunities are, the smaller the difference in their values) and convex for losses (the further away from the reference point, the greater the difference between the state of things)" (Kahneman, Tversky 1979: 267). The main conclusion stemming from the theory is that economic entities are more cautious of losses than appreciative of profits. This is also due to a strongly felt need to maintain the status quo. Another important assumption of this theory is a declining sensitivity to losses. Kahneman and Tversky considered their theory to stem from descriptive knowledge obtained as a result of empirical research. Even if the descriptive model of decision-making in uncertain situations contains certain simplifying and idealizing assumptions, it is still more realistic than the classical model explaining human behaviour in the economic and financial sphere and referring to the neo-liberal (marginalist) school. Prospect theory has found its wide application in behavioural finance.

The beginnings of behaviourism in economics and finance trace back to the turn of the nineteenth and 

and New Zealand

twentieth century. A broader interest in this midstream research began when Kahneman received the prize in economics (despite being a psychologist) and Tversky got recognized for the prospect theory in 2002. Since then the trend of behavioural economics has been implemented in economic and financial sciences.

Other cognitively relevant results of research conducted in the field of behavioural economics include the following:

- the concept of ownership (people value an object more when they already possess it than before);

- the theory of hyperbolic discounting (describing a tendency that earlier profits are preferred over the latter, the closer they are to the present),

- considering the role of emotions and social preferences in the analysis of decisionmaking processes.

Behavioural Economics and Pension Economics. Behavioural economics has been used to explain the phenomena occurring on the financial market, and especially regarding the behaviour of investors. From the point of view of pension economics, it is important that the retirement savings behavioural theory has also been established along with retirement behavioural theory.

Thaler presents in pictorial and accessible ways the differences between the theory of saving based on the neoclassical homo oeconomicus paradigm and the behavioural theory of saving. He has also authored and co-authored numerous papers where specific assumptions of the behavioural concept of saving are presented with the use of advanced mathematical apparatus, including econometric models.

According to Thaler, conventional (micro) economic thinking assumes that all people are "Econs," i.e. economic entities who make rational financial decisions on the basis of the analysis of relevant facts (objectively, without bias, on the basis of clearly defined and unchangeable criteria in the decision-making process), are emotionless calculators seeking optimal choices (acting analogously to a properly programmed computer) and have no problems with self-control or weak will. In fact, we are not dealing with the "Econs" (acting in accordance with the homo oeconomicus paradigm), but only humans who have limited capacity to collect, process and analyze data, suffer limitations, are biased, susceptible to emotions and often take decisions inconsistently and even irrationally (Mullainathan, Thaler 2000: 3-5).

The following theoretical assumptions and the results of experimental studies of behavioural economics have been applied to pension economics:

1. The concept of bounded rationality. Many people do not possess sufficient knowledge or intellectual competence to make complex choices regarding retirement plans, financial instruments, and accumulation methods or properly spaced out pension capital. Even people with sufficient knowledge and competence may not have enough time or motivation to handle it. Effective saving and long-term investment under the conditions of misinformation and risk pose a very serious challenge usually undertaken for the first time in people's lives. If a Nobel Prize winner and the co-inventor of the modern portfolio theory believes that proper planning to save for retirement poses a serious problem, what then can an average person not involved in the financial market say? As Steve Vermon from the Stanford Center on Longevity (USA) rightly observes, under conditions of increasing life expectancy and various types of risk on the financial market where pension savings are placed, the participants of occupational pension schemes with defined contributions must be their own actuaries (including life expectancy and retirement period) and their own investment advisors (Vermon 2016: 1). It is not surprising that, without sufficient competence, they commit serious mistakes (e.g. save less than they can and should in the accumulation phase of additional pension capital or make erroneous choices in the consumption phase of the accumulated financial resources, leading to their premature exhaustion) or permanently postpone or abstain from participating in supplementary pension schemes.

A solution to the errors in the planning and implementation of pension plans resulting from limited rationality can involve providing all those interested with specialist advice, as well as the implementation of suitably constructed compulsory or quasi-compulsory occupational pension schemes. 
2. Loss aversion - a phenomenon where individuals suffer more painfully experiencing loss than when they enjoy profit (involving the same amount of money). This phenomenon of decision-making leads to a situation when people do not take advantage of opportunities to achieve above-average profits while still able to (e.g. young people whose retirement savings can at least partially be invested in equities). Solutions that limit loss aversion may include, for example, occupational pension schemes with life cycle funds where the proportion of financial assets changes with the age of participants (from riskier investments in stocks through mixed stock, bond, commercial papers, etc., up to the safe ones - financial market instruments or treasury debt securities).

3. Formatting or framing - refers to the way people perceive alternatives regarding which they have to make choices and suffer possible consequences of their decisions. One of the obstacles to the proper "formatting" of the available alternatives and making the right choices is choice overload. In order to counter this, it is advisable, according to behavioural economics guidelines, to limit the number of available alternatives, or provide professional advice (Samson 2015: 23).

Formatting can also refer to the presentation of selected options with an emphasis on possible losses or possible benefits, using the risk aversion phenomenon described in the prospect theory.

4. Default solutions that do not require active selection or undertaking any actions (defaults) -utilizing internal psychological mechanisms (including the desire to retain status quo) and social norms (e.g. imitating others in social or occupational groups) to achieve the intended results. Such default options are widely used in numerous pension schemes, such as occupational pension schemes with automatic enrolment where participants are able to withdraw within a specific time frame. As leaving the scheme requires additional effort and maintaining the status quo does not, and in addition participants observe that for most employees the participation is the norm, in practice only a small number of individuals withdraw from their occupational pension schemes (Vernon 2016: 42).

The default options may concern not only the participation in the occupational pension schemes but also the choice of one of its available forms (both in the accumulation phase and in the withdrawal phase).

5. Procrastination (postponing, pushing away a decision) - a very common occurrence that makes it more difficult to decide on additional retirement savings, especially for younger and lower-income people, often associated with financial myopia. Both of these phenomena are psychologically determined. This has also been confirmed in the research by Thaler and Bernard (2001). Analysing the reasons for low savings the authors noted that the lack of sufficiently strong will on the part of the future pensioner is critical. To make a decision on additional retirement savings requires significant self-control and a will to reduce current expenditure. It is not enough just to be aware of the need for additional savings. Both these phenomena (procrastination, financial short-sightedness) identified on the basis of research conducted in the perspective of behavioural economics have also been confirmed in empirical studies on behaviour in Polish households.

Reducing the time necessary to make a choice is a method to counter procrastination recommended by the representatives of behavioural economics.

Another one involves an appropriate design of the decision-making process (choice architecture) using the aforementioned default options that maximize and simplify inclusion in the supplementary pension scheme (Choi et al. 2009a) or a "decoy effect." The latter result is also known as the asymmetrically dominated choice and occurs when the preference for one option over the other is altered by an addition of a third one (a similar or a less attractive one). For example, consumers are more likely to choose more expensive equipment if a third and more attractive one is added to broaden the choice (Bateman, Munro and Poe, 2008). The same rule may apply to pension products or providers of more or less reputable financial services.

6. Mental separation "separated accounts" of different financial resources (mental accounting) taking a parallel, non-integrated financial decisions on various aspects of life. In this way, there is no 
portfolio of mutually complementary investments of different time horizons.

Behavioural economics makes it possible to increase the attractiveness of long-term investments integrated with short-term ones. For example, it is possible to use computer software to visualize one's appearance in 40 years, and thus visualize future financial needs or financial reward mechanism for current consumption after reaching certain milestones in long-term savings.

The Use of Behavioural Economics in Pension System Reform. In Great Britain - a Case Study. An example of the use of defaults to restrict procrastination, delaying decisions to start saving was an automatic enrolment of workers to the UK's occupational pension schemes with an option to opt out.

This solution has been successively implemented since 2012 (until 2018) in order to increase the level of participation in occupational pension schemes, increase the rate of replacement of retirement income relative to the period of professional activity and ultimately reduce the dependence on the public pension scheme, which provides only basic financial security for old age (basic security against poverty). It obliges employers to include in the qualifying occupational pension scheme all employees who meet certain criteria of age (at least 22 years old), income (at least $£ 10,000$ per year), and who work exclusively or primarily in the UK and pay at least the minimum contribution (Department for Work 2016:1). Employees with lower incomes are also entitled to join occupational pension schemes but on a voluntary basis. Enrolled employees have the option of opting out. After three years, employers are obliged to enrol them once again unless they resign voluntarily. Quitting the program within a month entitles employees to recover their contributions (but without employer's contribution and a tax deduction), but opting-out later results in the suspension of the previously paid contributions until an employee reaches retirement age. This prevents excessive fluctuations in the funds collected in occupational pension schemes and enables financial service providers that support the pension scheme to invest effectively. Most people, however, remain and continue to save for retirement at their workplaces. Initially, auto-enrolment covered only large employers, then medium ones, and by 2018 all employers (large, medium and small enterprises and other workplaces) will be required to include their employees in an occupational pension scheme and pay the required contribution themselves and for their employees.

The amount of the minimum contribution by employees, employers and tax deductions supporting retirement savings at the workplace are shown in Table 1.

From April 2019 minimum employer contribution will be 3\%, minimum employee contribution 5\%, total contribution to a pension scheme: $8 \%$. According to data at the end of March 2015, occupational pension schemes automatically included 5.2 million new employees since the start in 2012. This has helped to curb the decline (in the private sector) and cause a significant increase in occupational pension insurance contributions up to $75 \%$ of participants (both public and private), compared to $55 \%$ in 2012 . Particular attention should be paid to a saccadic increase in the number of retirement-saving employees in workplaces employed by private companies (from $42 \%$ in 2012 to $70 \%$ in 2015). The increase in occupational pension scheme participation in the public sector was smaller (from $88 \%$ in 2012 to $91 \%$ in 2015 ) as the initial participation (in the occupational pension scheme ranked as the second-tier pension system) had been very high. This means that saving in an occupational pension scheme has become the norm for most workers in the UK (The Pensions Regulator 2016, p. 3).

Analyses commissioned by the British Government show that if the program continues to be consistently implemented (and nothing indicates otherwise, even after the UK leaves the European Union), the following macro effects can be expected between 2012 and 2019. (Department for Work ... 2016: 1):

- 17 billion pounds sterling a year of new savings in occupational pension schemes, of which 6 billion will be employer-paid contributions, 8 billion will be paid by employees, and 2 billion will be the effect of tax incentives for employees (income tax relief).

- $3 / 4$ of all employees qualify for auto-enrolment, of which $63 \%$ are women and $72 \%$ are ethnic minorities. 
Table 1 - The level of contributions and tax deductions in occupational pension schemes with auto-enrolment in the UK (2012-2018) (based on Pensions Regulator 2018)

\begin{tabular}{|c|c|c|c|c|}
\hline Time Period & $\begin{array}{c}\text { Minimum } \\
\text { contribution by the } \\
\text { employee }\end{array}$ & $\begin{array}{c}\text { Minimum contribution } \\
\text { by the employer }\end{array}$ & Tax relief & $\begin{array}{c}\text { Minimum total } \\
\text { contribution (employer } \\
\text { and employee) }\end{array}$ \\
\hline $\begin{array}{c}\text { Since 1 January } \\
2012 \text { until } 30 \\
\text { September } 2017\end{array}$ & $\begin{array}{c}0.8 \% \text { of qualified } \\
\text { income* }\end{array}$ & $\begin{array}{c}1 \% \text { of qualified } \\
\text { employee income }\end{array}$ & $\begin{array}{c}0.2 \% \text { of qualified } \\
\text { employee income }\end{array}$ & $\begin{array}{c}2 \% \text { in the period from } 1 \\
\text { January } 2012 \text { until } 30 \\
\text { September } 2017\end{array}$ \\
\hline $\begin{array}{c}\text { Since 1 October } \\
2017 \text { until } 30\end{array}$ & $\begin{array}{c}3 \% \text { of qualified } \\
\text { income* }\end{array}$ & $\begin{array}{c}\text { minimum } 2 \% \text { of } \\
\text { qualified income* }\end{array}$ & $\begin{array}{c}\text { Up to } 1 \% \text { per year } \\
\text { of qualified } \\
\text { employee income }\end{array}$ & $\begin{array}{c}5 \% \\
\text { of qualified income* }\end{array}$ \\
\hline $\begin{array}{c}\text { As of October } 1, \\
2018\end{array}$ & $\begin{array}{c}4 \% \text { of qualified } \\
\text { income* } \\
\text { during }\end{array}$ & $\begin{array}{c}3 \% 18 \\
\text { qualified income* } \\
\text { In the period from 1 } \\
\text { October } 2018\end{array}$ & $\begin{array}{c}\text { Up to } 1 \% \text { per year } \\
\text { of qualified } \\
\text { employee income }\end{array}$ & $\begin{array}{c}7 \% \\
\text { of qualified income* }\end{array}$ \\
\hline
\end{tabular}

Note: Qualified income is assumed to be gross income (salary with all permanent allowances of at least $£ 10,000$ per year).

Data on automatically enrolled employees who opted out of the program during the first month and withdrew their contributions come from a quantitative survey conducted in 2013 over a representative sample of 3,000 employers, and a qualitative survey involving enterprises included in the quasicompulsory occupational pension scheme in 2014 (Automatic Enrollment 2014). Both of these studies show that the percentage of workers who opted out of the occupational pension scheme in which they had been enrolled automatically was relatively small - between $9 \%$ and $10 \%$ in $2012-2014$. This is much less than originally accepted during the program's start-up phase in 2012 when it was assumed that up to $30 \%$ of employees had opted out. People with the lowest income predominated in the first month after enrollment among those who opted out. As a matter of fact, there were also problems with the implementation phase of the reform, as well as political and ideological controversies (e.g. the allegations of abandonment of traditional liberal doctrine stating the freedom of choice and individual resourcefulness and responsibility to ensure prosperity in old age for the participants and their loved ones).

Despite the generally positive (in the light of the presented statistics) effects of the implementation of the reform of occupational pension schemes in the UK, there have also appeared numerous sceptical voices. For example, Pitt-Watson, D. (2011) or Davis (2012) indicate that the automatic enrollment in a defined contribution pension scheme offers only a specific financial product (an investment account in a pension scheme) but no additional pension, because there is no guarantee of future benefits (as in the previous schemes with defined benefits). Financial institutions (providers) that support occupational pension schemes are the biggest beneficiaries, and not the participants themselves. There have also been cases of misspelling (offering pension products mismatched to customer needs and financial situation). The following slogan included in the program document preceding the introduction of auto-enrolment: "Security in Retirement" (Department of Work and Pensions, 2006) has turned out to be too optimistic.

Conclusions. Based on the analysis of the effects of the reforms of occupational pension schemes in Great Britain, it is possible to conclude that behavioural economics has been implemented successfully. The success of the British reform has been determined by the default option where an employee automatically enrolled in the occupational pension scheme is to remain in the program and co-pay contributions together with their employer. Quitting the program required taking the initiative and violating the status quo. In addition, a broad educational campaign has been launched, demonstrating a long-term benefit for both employees and employers (appropriate mental "formatting"), and the choice of an opt-out option (withdrawal in the first month and the recovery of the first contribution) as riskier (the mechanism of 
psychological risk aversion).

The UK pension reformers were aware that both employees and employers operate under bounded rationality, and do not demonstrate complete knowledge about the financial market or other relevant parameters of pension systems (e.g. life expectancy of individual groups of employees). In this situation, the use of behavioural economics has carried the desired effect: increasing the level of participation in occupational pension schemes and the state of long-term pension savings. If volunteering to participate in occupational schemes was left as an option, the default was absent, and joining the program required additional employee involvement, a significant proportion of workers - especially those with lower education and retirement awareness or lower incomes (as before the introduction of the automatic enrolment) would delay the decision (procrastination), and show reluctance to violate the status quo. Moreover, as experienced by different countries, mainly people of higher income would save for retirement in order to benefit from tax allowances.

There are also threats associated with the introduction of behavioural economics solutions to promote participation in supplementary pension schemes. They must be well prepared regarding organizational, institutional and financial-economic perspectives. For example, the automatic enrollment cannot overstate the employer's cost of labour. In addition, the mandatory or quasi-compulsory inclusion of people with very low wages in occupational pension schemes makes no sense, as it is likely to result in very low "junk" benefits (Czepulis-Rutkowska 2016:10). Behavioural economics should be applied in accordance with the principles of corporate social responsibility in order not to lead to misspelling (selling offensive, inadvertent, or harmful products to their buyers) or manipulating the behaviour of pension scheme participants against their interests.

The analysis of the implementation of occupational pension schemes with automatic enrollment demonstrates that the introduction of a similar solution in Poland constitutes a real chance for the dissemination of occupational pension schemes and would provide impetus to the development of the third pillar of the pension system in the country. There are numerous indications suggesting that UK-based occupational pension schemes with auto-enrollment will be introduced in Poland in the form of occupational pension schemes announced in the program by Deputy Prime Minister Mateusz Morawiecki (The Ministry of Development, 2017). This may happen in 2017 or 2018.

Acknowledgement. Some of the results of the research on pension economics presented in this paper have been obtained from statutory research at the Faculty of Economic Sciences of Poznań University of Technology (project title: "The study of economic and social problems of the Polish economy in the context of European integration and globalization").

Camerer, C., F., Loewenstein, G., Rabin, M., (2004). Advances in behavioural economics. Princeton and Oxford: Princeton University Press.

Cordes, J., (1990). Socio-economic perspectives of household savings. Journal of behavioral economics, 19 (3), 273-284

Czepulis-Rutkowska, Z. (2016). Przegląd emerytalny 2016 - Bezpieczeństwo dzięki odpowiedzialności [Retirement Review 2016 - Security thanks to responsibility], Polityka Spoleczna, 1, 7-12.

Davis, B. (2012). Better Defined Contributions Pension Provision, TUC Working Paper (Trade Unions Congress), London.

Department for Work and Pensions (2016). Security in Retirement. Towards a New Pension System. [pdf] London: Department for Work and Pensions [online]. Retrieved from

http://webarchive.nationalarchives.gov.uk/20100407120701/http:/dwp.gov.uk/docs/prelims.pdf .

http://www.thepensionsregulator.gov.uk/en/employers/phasing-increase-of-automatic-enrolment-contribution.

Kahneman, D., Tversky, A., (1979). Prospect theory, an analysis of decisions under risk. Econometrica, 2(47), 263-292.

Knoll, M., (2010). The Role of Behavioral Economics and Behavioral Decision Making in Americans Retirement Savings Decisions, Social Security Bulletin, 4(70).

Mullainathan, S., Thaler, R. (2000). Behavioural Economics, NBER WORKING PAPER SERIES, Working Paper 7948. Retrieved from http://www.nber.org/papers/w7948.

Pensions Regulator (2018). Retrieved from; http://www.thepensionsregulator.gov.uk/docs/automatic-enrolment-businessadvisers-events-2018.pdf 
Pitt-Watson, D. (2011). Tomorrows' Investor, Pensions, 191-205. Retrieved from

Skarżyńska, K., (2006). Człowiek a polityka. Podstawy psychologii politycznej [Man and politics. Basics of political psychology]. Poznań: ZYSK I S-KA.

Skarżyńska, K., (1999). Psychologia polityczna [Political psychology]. Poznań: ZYSK I S-KA.

Szczupaczyński, J. (ed.), (1993). Elity.Wybory. Demokracja [Elite. Elections. Democration]. Warszawa: Agencja Scholar.

Szumlicz, T. (2005). Ubezpieczene społeczne teoria dla praktyki [Social insurance theory for practice]. Bydgoszcz-Warszawa: Oficyna Wydawnicza Branta.

Thaler, R., (2000). From Homo Economicus to Homo Sapiens. Journal of Economic Perspectives 14(1), 133-141.

Thaler, R., Bernarzi, S., (2001). Save More Tomorrow: Using Behavioral Economics to Increase Employee Saving. Los Angeles: University of California.

Thaler, R., Sustein, C. (2008). Nudge. Improving decisions about health, wealth and happiness, Yale: Yale Univesity Press.

Tyszka, T., 1999. Psychologiczne pułapki oceniania i podejmowania decyzji [Psychological pitfalls of assessing and making decisions]. Gdańsk: Gdańskie Wydawnictwo Psychologiczne.

Zaleśkiewicz, T. (2011). Psychologia ekonomiczna [Economic psychology], Warszawa: PWN.

Zinn, J., O. (2004), Literature Review: Economics and Risk, Social Contexts and Responses to Risk Network (SCARR), Working Paper 2004/2. Retrived from: https: www.kent.ac.uk.

М. Щепанскі, Познанський технологічний університет (Познань, Польща).

Впровадження основних принципів поведінкової економіки при реформуванні пенсійних систем: досвід Великої Британії та Нової Зеландії

Метою статті є оцінка результатів врахування принципів поведінкової економіки як одного з найбільш інноваційних напрямків в економічній науці, при реформуванні пенсійної системи. Дослідження зосереджено на аналізі використання теорії поведінкової економіки при реформуванні недержавної пенсійної програми (передбачає автоматичне зарахування 3 можливістю виходу у певний час) на прикладі досвіду Великобританії. Ефрективність британської рефрорми пояснюється тим, що всі працівники автоматично зараховувались до недержавної пенсійної програми, що передбачала партисипативну сплату внесків працівників і роботодавців. При цьому вихід із програми можливий лише за ініціативою працівника з порушенням його статус-кво в організації. В роботі висвітлено роль поведінкової економіки у реформуванні пенсійної системи Великобританії. Автори пояснюють, що обмеженість раціональної поведінки працівників та роботодавиів, в умовах обмеженості знань про фінансовий ринок та інші відповідні параметри пенсійних систем (наприклад, тривалість життя окремих груп працівників) вплинуло на збільшення рівня участі громадськості у даній системі та обсягів довгострокових пенсійних накопичень. Окрім цього, була запущена широка просвітницька програма яка демонструвала довгострокові переваги як для роботодавців, так і для працівників. При цьому пояснювались шляхи та ризики виходу з даної програми. В рамках дослідження обгрунтовано можливості та переваги впровадження в Польщі британської ресрорми пенсійної системи з автоматичним зарахуванням, що тим самим призведе до імпульсу розвитку третього рівня пенсійної системи країни. Поряд із цим автор виокремлює загрози реформування пенсійної системи з урахуванням елементів теорії поведінкової економіки.

Ключові слова: поведінкова економіка, пенсійні реформи, державні та додаткові пенсійні схеми.

http://mmi.fem.sumdu.edu.ua/en 